\title{
trabahonecessário
}

issn: $1808-799 \mathrm{X}$

ano 3 número $3-2005$

\section{NEDDATE 20 ANOS}

Ronaldo Rosas Reis

Gaudêncio Frigotto

Criado em 1985 pelos professores Maria Ciavatta e Gaudêncio Frigotto como um "Programa de Pesquisas sobre Trabalho e Educação" vinculado à Pós-Graduação, o Neddate vem mantendo, desde então, projetos de pesquisa e de orientação de dissertações de Mestrado, teses de Doutorado e monografias de Graduação sobre as relações entre o mundo do trabalho e a educação, sempre desenvolvidos a partir do método do materialismo histórico. Essas diversas atividades de pesquisa agrupam-se em torno de duas linhas: a) a reconstrução histórica da relação trabalho e educação e, b) a formação humana e o mundo do trabalho. Como núcleo de documentação e dados o Neddate mantém um acervo de mais de 2000 documentos, sendo 300 teses e dissertações, 400 revistas especializadas, 700 artigos selecionados, 300 documentos dentre anais, índices, relatórios, projetos, etc.

Em 1996, quando então realizou um balanço sistematizado de uma década de atividades, o Neddate publicou o seu primeiro Boletim impresso (Boletim do Neddate. Número zero. Niterói: UFF, setembro de 1996) . Nele, o corpo de pesquisadores do Núcleo sinalizava, dentre outros aspectos "as mudanças no mundo do trabalho, a reestruturação produtiva, a nova organização do trabalho, tanto pela introdução de novas tecnologias, como pela reorganização dos processos de trabalho". Avaliando o quadro de exacerbação das mudanças implementadas pela política econômica neoliberal nos governos Collor de Mello, 
Itamar Franco e Fernando Henrique Cardoso, o documento concluía, sombriamente, ter havido o aniquilamento da maior parte dos direitos sociais no país.[1]

Quatro anos depois, no limiar do atual milênio, o Núcleo produziu um novo documento no qual os pesquisadores do Núcleo analisavam a conjuntura que se apresentava desde o último balanço, realizado em 1996, e inventariavam criticamente a problemática "divisão das forças progressistas e a derrota do movimento social organizado", criada a partir da promulgação da nova Lei Diretrizes e Bases da Educação Brasileira (Lei 9.394/96). [2]

Na mesma linha crítica, o documento chamava a atenção para o processo de fragmentação da educação profissional, exarcebado pela criação do PLANFOR, em 1995, e das resoluções de cunho flexibilizante que Ihe seguiram. Em suma, a partir da análise do conjunto de ações políticas e econômicas implementadas no curso de dois mandatos do presidente Fernando Henrique Cardoso, o documento sinaliza a constituição, no campo das relações entre o trabalho e a educação, de um "ideário do capital como política oficial e unidimensional do Estado brasileiro".[3]

Após dois anos de governo Lula, o Neddate não produziu ainda uma análise coletiva deste importante período. Mas, como veremos mais adiante, o debate se inicia no presente número.

A necessidade de ampliar o espectro de leitores e de incorporar outros pesquisadores ao debate travado internamente ao Núcleo, levou o Neddate a criar, em 2003, em substituição ao seu boletim impresso, a presente Revista Eletrônica.

Em seu primeiro número (azul), Trabalho Necessário disponibilizou, dentre outros textos, artigos de Ramon Peña Castro e de Maria Ciavatta, ensaios de Leandro Konder e Paulo Sérgio Tumolo, além do documento histórico que relata os debates ocorridos, em 2002, na UFF, no Intercrítica - I Encontro Nacional de Núcleos sobre Trabalho e Educação.

No segundo número (vermelho), disponibilizado em 2004, a expectativa que tínhamos era de crescimento, fato que se confirmou dada a presença de um número maior de autores que apresentaram trabalhos. Dentre eles, os artigos de Justino de Souza Júnior, de Roseli Salete Caldart, os ensaios de Sonia Regina Mendonça e de Sonia Maria Rummert, além 
do memorial centenário da educação profissional, apresentado por Francisco José Silveira Lobo Neto.

O presente número 3 de Trabalho Necessário (preto e branco), ainda aberto a novas colaborações, traz, especialmente, uma seção intitulada "debate". Nela apresentamos os textos do riquíssimo debate em torno do novo decreto da educação profissional. São eles: "Quarenta anos adiante: breves anotações em torno do novo decreto da educação profissional", de José Rodrigues, e "A gênese do decreto 5.154: um debate no contexto controverso da democracia restrita", de Maria Ciavatta, Marise Ramos e Gaudêncio Frigotto. Como se poderá notar na chamada do letreiro do índice, a revista abre o seu espaço para a intervenção do leitor interessado em participar diretamente desse debate. Além destes, o leitor encontrará ainda, nas seções habituais, textos que esperamos que venham estimulá-lo à participação crítica.

Conforme indicamos na linha editorial da Revista, Trabalho Necessário é um dos conceitos centrais do pensamento marxiano. Conceito que, se por um lado, refere-se à atividade vital do ser humano, e, também, à medida e à substância do valor, por outro lado remete à compreensão de que o embate teórico e prático pela superação da sociedade das mercadorias não pode ser deixado de lado. Enfim, o trabalho será sempre necessário.

[1] CIAVATTA, M. FRIGOTTO, G. TREIN, E., RODRIGUES, J., TIRIBA, L., ANTUNES, J.L., RUMMERT, S.M. Neddate. Balanço de atividades e perspectiva. Boletim do Neddate número 4. Niterói: Universidade Federal Fluminense, 2000.

[2]Idem

[3]Idem

volta 